\author{
Paula Wiśniewska \\ University of Wrocław \\ paula.wisniewska1992@gmail.com
}

\title{
The Mechanism of Quota in the Light of Electoral Code Regulations Introduced in 2011
}

\begin{abstract}
The article describes the process of introducing the electoral quota system into Polish legislation. This system is one of the most popular instruments forincreasing the participation of women in politics. Women are underrepresented in the Polish Parliament with only $23.9 \%$ of politicians being female. This situation was supposed to be changed by implementing the electoral quota system, which requires the equal number of $35 \%$ male and female candidates in the electoral polls for all parliamentary, district council and county council elections. The first draft of the electoral quota act was the Parity Act, proposed as one of the people's legislative initiatives in 2009. The article also describes the attempts to increase the required number of $35 \%$ male and female candidates by implementing the clause which sets the rule of placing the names of female and male candidates alternately on the electoral polls, thesocalled "zipquota".
\end{abstract}

Keywords: Women in politics, electoral quota, parity system, electoral list, act of 2011

Słowa kluczowe: Kobiety w polityce, kwoty wyborcze, parytety wyborcze, listy wyborcze, kodeks wyborczy z 2011 roku

\section{Introduction}

Women gained the right to vote and stand in elections in Poland in the year 1918 under the decree on electoral law issued by Józef Piłsudski. Already in the year 1919, they were eligible for political offices and could stand in the elections to the Legislative Sejm. Despite the fact that the women in Poland were the first in Europe to obtain the suffrage, their representation in the Polish parliament is still rather small. In the year 1991, there were 10\% of women in the Sejm and 8\% in the Senate. In 1993, their percentage in the Sejm and Senate increased to 13\%. During the term of office of the Sejm in the year 1997, the percentage of women was kept at the level of $13 \%$, and in the Senate, it fell to $12 \%$. It was only after the elections in the year 2001 that the women's representation increased to $20 \%$ in the Sejm and 
$23 \%$ in the Senate. The percentage of women in the Sejm both after the elections in the year 2005 and 2007 was still at the level of $20 \%$ while in the Senate it decreased to $14 \%$ in 2005 and $8 \%$ in $2007^{1}$. The low level of participation of women in the parliament is not only a problem in Poland. It also affects the whole of Europe. The globally applied mechanisms which are aimed at facilitating the use of the right to be elected by women are electoral gender quotas and parities. Such a solution was adopted, among others, in France, Belgium and Slovenia. The Women's Congress ${ }^{2}$ in 2009 triggered discussions in the Polish media and political circles, regarding the introduction of parities into the Polish electoral law, which resulted in the adoption of the so called Quota $\mathrm{Act}^{3}$ in 2011. However, before the act was passed, it went through a long legislative path and its original provisions were amended significantly. In the final version, it introduced the electoral quotas and not parities as the act initiated by citizens originally proposed. As the elections in the year 2011 demonstrated, the adopted solution did not ensure a significant increase in the representation of women in the Sejm. The consequence of this was another draft act which introduced the zipping principle to alternate between male candidates and female candidates on the electoral list. This study will discuss the assumptions of the parity act initiated by the citizens, then the act of 2011 on amendment to the laws for elections to the Sejm, Senate, municipal council and European Parliament will be subjected to analysis and finally the consequences resulting from the entry of the act into force will be shown together with the possible options for improvement of these legal solutions.

\section{Quotas or perities - definitions}

In the political discourse and in the media, the terms 'quotas' and 'parities' are misused; these two words are applied interchangeably, though their meanings are different. Parities (in Latin paritas, franc. parité means equality) ${ }^{4}$ occur in a situation in which the requirement of representation of one group constitutes an adequate number to the percentage of that group in the entire population. In the case of electoral parities, this means that the $50 \%$ winnable seats on the lists should be taken

1 B. Balińska, Polityka równości płci Polska 2007 Raport, Warszawa 2007, p. 25.

2 The Congress of Women is a social movement, activizing socially and politically women in Poalnd. The starting point were activities undertaken when organizing the First Congress of Women, that is a convention of more than 4 thousand women from all over the country, who discussed women contribution to the history of the last two decades in Poland.

3 Ustawa z dnia 5 stycznia 2011 r. o zmianie ustawy - Ordynacja wyborcza do rad gmin, rad powiatów i sejmików województw, ustawy - Ordynacja wyborcza do Sejmu Rzeczypospolitej Polskiej i do Senatu Rzeczypospolitej Polskiej oraz ustawy - Ordynacja wyborcza do Parlamentu Europejskiego (Dz.U. z 2011 r. Nr 34, poz. 172) [Journal of Laws of 2001 No. 34 item 172]. 
The Mechanism of Quota in the Light of Electoral Code Regulations Introduced in 2011

by women. Quotas are defined by Pippa Norris ${ }^{5}$ as 'the instrument which introduces specific criteria in the form of the minimum or maximum threshold for a given group, into the procedure for selection of members to the bodies coming from universal elections or from the nomination in the public sphere or to the recruitment in the private sector. ${ }^{6}$ Thus the quotas do not specify precisely what percentage ratio between a group of women and a group of men should exist. The quota system may be introduced at the constitutional and statutory level, but also in internal regulations of political party ${ }^{7}$. In France, the introduction of electoral gender quotas was bound to the amendment to the constitution. In Poland, there are statutory quotas, but before the year 2011, they also appeared in internal regulations of the parties - these were the so called voluntary quotas (Left-Wing Alliance, Labour Party, Freedom Union and Civic Platform $)^{8}$. We can also face a situation in which failure to fulfil the quota requirements entails consequences in the form of lack of registration of the electoral list (Poland, Slovenia), leaving of a blank place, if no women starts from it (Belgium), or results in the reduction of the financing of the party from the public funds (France) $)^{9}$. In some countries, we can encounter zipping which is a type of quotas that introduces the obligation to alternate between women and men on electoral lists. In Australia and New Zealand, women's lists of candidates are notified, that is, the said lists comprise women exclusively ${ }^{10}$. In the case of single-mandate constituencies in Wales and Scotland, the twinning of districts is observed, i.e. the candidates from the neighbouring constituencies are notified in pairs - a woman is a candidate in one constituency and a man in the other.

\section{Attempts at introducing electoral parities to Poland}

The first proposal for introduction of quotas in Poland was presented in the 1990's, within the framework of the act on the equal status of women and men. The draft act assumed the introduction of a requirement of the $40 \%$ representation of candidates on electoral lists and in all the bodies nominated and appointed by the authorities. The draft was lost in the committee before the expiry of the term of office of the Sejm in $1997^{11}$. The proposal for introduction of the quota system was put

5 Pippa Norris - an American political scientist, focusing in her research on equal opportunities for women and men in politics.

$6 \quad$ Ł. Wawrowski, Polityka równych szans. Instytucjonalne mechanizmy zwiększania partycypacji kobiet w struktu- rach politycznych na przykładzie państw Unii Europejskiej, Toruń 2007, p. 587.

$7 \quad$ M. Fuszera, Kobiety, wybory, polityka, Warszawa 2013, p. 19.

$8 \quad$ Ł. Wawrowski, Polityka..., op. cit., p. 592.

9 Ł. Wawrowski, Polityka..., op. cit., p. 592.

10 M. Szewczyk, Parytet płci w ujęciu prawno-porównawczym, "Studia Iuridica Toruniensia" t. 9/211, Toruń 2011, p. 145.

11 M. Fuszera, Kobiety..., op. cit., p. 21. 
forward again in the Polish Sejm by the Freedom Union and the Parliamentary Group of Women before the parliamentary elections in the year 2001. The parties proposed an amendment to the electoral law by introducing the obligatory requirement of $30 \%$ of women on electoral lists. The consequence of failure to fulfil the requirement of $30 \%$ would be the lack of registration of such a list. However, in the end, this solution was not accepted. Again, the problem of under-representation of women on electoral lists was touched upon at the Women's Congress in 2009. The Congress was organised under the name 'Women for Poland. Poland for Women', and one of its proposals was to amend the electoral law by introducing a provision regarding the parities on electoral lists. It was argued that women have no equal chances in politics, are under-represented, and this translates into their insufficient representation in the composition of parliaments. In October 2010, the Citizen's Committee for Legislative Initiative 'Time for Women' referred the draft act on amendment to the provisions of the Act on Elections to the Sejm and Senate of the Republic of Poland, provisions of the Act on Elections to Municipal and County Councils and Provincial Assemblies and provisions of the Act on Elections to the European Parliament, in connection with the introduction of the gender parity to candidate lists ${ }^{12}$.

The draft proposed the inclusion of the following paragraph in the provisions for elections to the Sejm and Senate - in Article 143:

'The number of women on the regional list must not be lower than the number of men'13.

In the provisions of the Act on elections to municipal and district councils and provincial assemblies, section $2 \mathrm{a}$ was to be added to Article $43^{14}$.

'The number of women on the list may not be lower than the number of men. This principle is not applied in the case of supplementary elections to the council in a municipality inhabited by up to 20,000 people'.

In the rationale provided for the act initiated by the citizens, a reference was made to the principle of equality before the law guaranteed in Article 31, section $1^{15}$ of the Constitution of the Republic of Poland and the principle of equal treatment of

12 Obywatelski projekt ustawy - o zmianie ustawy - Ordynacja wyborcza do Sejmu Rzeczypospolitej Polskiej i Senatu Rzeczypospolitej Polskiej, ustawy - Ordynacja wyborcza do rad gmin, rad powiatów i sejmików wojewódz- kich oraz ustawy - Ordynacja wyborcza do Parlamentu Europejskiego, w związku z wprowadzeniem parytetu płci na listach kandydatów, Sejm paper No. 2713, p. 5.

13 Obywatelski projekt ustawy - o zmianie ustawy - Ordynacja wyborcza do Sejmu Rzeczypospolitej Polskiej i Senatu Rzeczypospolitej Polskiej, ustawy - Ordynacja wyborcza do rad gmin, rad powiatów i sejmików wojewódz- kich oraz ustawy - Ordynacja wyborcza do Parlamentu Europejskiego, w związku z wprowadzeniem parytetu płci na listach kandydatów, Sejm paper No. 2713, p. 6.

14 Ibidem.

15 Konstytucja Rzeczypospolitej Polskiej z dnia 2 kwietnia 1997 roku (Dz.U. z 1997 r. Nr 78, poz. 483 z późn. zm.) [Journal of Laws of 1997 No. 78 item 483 as amended]. 
women and men established in Article 33 of the Polish Constitution, including the right of women to hold public offices and receive public honours. An observation was made in the rationale that despite the fact that 'women constitute the lasting majority' of the citizens as a whole, they constitute a minority in the percentage composition of the public state authorities coming from the universal elections ${ }^{16}$. Doubts appeared among constitutionalists and lawyers, whether the Parity Act complies with the Constitution of the Republic of Poland in light of equality guaranteed by the Constitution. As well as non-constitutionality, the opponents of the draft raised the argument that the number of women on electoral lists was not specified exactly, so they could occupy $50 \%$ of places and more, without top-down limitations. Also, there were reservations that the draft interferes with the autonomy of political parties, and Article 11 of the Constitution of the Republic of Poland ensures freedom of establishment and operation of political parties in order to influence the shape of the state policy by means of democratic methods ${ }^{17}$. The opinions issued with regards to the draft act were contradictory and did not specify unambiguously whether the proposed draft act was conformant with the Constitution. The first reading of the act in the Sejm took place in January 2010, and then the draft was sent to committees and sub-committees. Civic Platform proposed an amendment in accordance with which candidates - both women and men were supposed to constitute $35 \%$ of persons on the list of candidates (in each case) in elections to the Sejm, European Parliament and local government. The ultimate solution adopted by the legislator is a compromise between the proposals of the Women's Congress and the draft parity act initiated by the citizens.

\section{Quota Act in Poland}

In January 2011, the president signed an Act that amended the electoral law for municipal and district councils and provincial assemblies, the electoral law for the Sejm and Senate of the Republic of Poland and the electoral law for the European Parliament. Provisions of the act were included in the Electoral Code from August $2011^{18}$. Article 211 of the Electoral Code, $\$ 3$ introduced the quota requirement on the electoral lists to the Sejm. The number of candidates - women, must not be lower than $35 \%$ of the number of all candidates on the list. Similar solutions were included in the regulations concerning elections to commune councils, Article $425 \$ 3$ of the Electoral Code. On the list referred to in $\$ 2$, point 2 of the Electoral Code:

\footnotetext{
$16 \quad$ Ibidem, p. 7.

17 A. Szmyt, Opinie w sprawie wprowadzenia parytetu płci na listach wyborczych, "Przegląd Sejmowy" 2010, No. 3(98), p. 137.

18 Dz.U. z 2011 r. Nr 34, poz.172 [Journal of Laws of 2011 No. 34 item 172].
} 
1) the number of candidates - women must not be lower than $35 \%$ of the number of all candidates on the list;

2) the number of candidates - men must not be lower than $35 \%$ of the number of all candidates on the list; ${ }^{19}$

In the specific provisions concerning elections to district councils, Article $457 \S$ 2 of the Electoral Code, in the case of notification of a list comprising 3 candidates:

1) the number of candidates -women

2) the number of candidates - men

- must not be lower than $1^{20}$.

Article $213 \S 1$ of the Electoral Code imposes a sanction on the electoral committee for failure to meet the quota requirements on electoral lists. No less than $35 \%$ of women and no less than $35 \%$ of men must be present on the electoral list in order to have it registered. The quotas may only be applied in the case of the proportionate electoral system. The amendment to the electoral law introduced single-mandate constituencies to the Senate and to the councils in municipalities with up to 20,000 inhabitants, therefore the quotas did not apply to electoral lists to the Senate and the council in municipalities with up to 20,000 inhabitants.

\section{Electoral gender quotas in parliamentary elections in 2011}

Shortly after the amendment to the electoral law for the Sejm and Senate, an opportunity appeared to check the effectiveness of the quotas in the parliamentary elections in the year 2011. As the amendment to the Code also involved the introduction of single-mandate constituencies to the Senate, the requirement for the $35 \%$ representation of each gender on the list of candidates to the second chamber of the parliament could not be fulfilled. The election committees of political parties presented the electoral lists to the Sejm taking into account the mechanism of quotas, most of the parties even exceeded the statutory minimum and the percentage of women on the lists was as follows: Left-Wing Alliance - 44.4\%, Civic Platform - 43.4\%, Polish Peasants Party - 41.7\%, Law and Justice - 39.8\%. ${ }^{21}$. Despite this, the number of women in the Sejm after the elections in 2011 increased only by 3.9 percentage point in comparison with the parliamentary elections in 2007, when women constituted $20 \%$. The reason for this minor increase can be sought in taking advantage of certain vagueness of the Act. The electoral law did not include any

19 Ustawa z dnia 5 stycznia 2011r. - Kodeks wyborczy (Dz.U. z 2011 r. Nr 21, poz.112 z późn. zm.) [Journal of Laws of 2011 No. 21 item 112 as amended].

20 Ibidem.

21 M. Fuszara, Kwoty, listy wyborcze i równość płci w wyborach parlamentarnych w 2011 roku, Warszawa 2012, p. 9. 
The Mechanism of Quota in the Light of Electoral Code Regulations Introduced in 2011

provisions regarding the place from which the female candidates and male candidates can start. No zippered quota was introduced, thus the electoral lists were designed by the political parties in such a way that women would often be put further down the candidate list. On the lists registered by the election committee of the Law and Justice party, there were $21.1 \%$ of women who occupied the first three positions ${ }^{22}$, while the first position was occupied by $24.8 \%^{23}$. In the case of Left Wing Alliance, female candidates in the first three positions constituted $36.6 \%$, while $15 \%{ }^{24}$ of women started from the first position. In Civic Platform $40.6 \%$ of women were found among the first three on the candidate list, and $34 \%$ of them started from the first position. In the Polish Peasants Party only $22.0 \%$ of women were assigned the first three positions on the list and 15\% of women were given number one. The Palikot Movement ranked $10 \%$ of women in the first position and the first three positions were occupied by $39.8 \%$ of women. The result of measures taken by the parties was an insignificant increase in the percentage of female candidates, which were elected to the Sejm. According to the internal policies of the parties, the first three positions on the list are more often than not taken by candidates who are recognisable by the voters and who have already served in several positions in the Sejm or Senate ${ }^{25}$. The Civic Platform and Law and Justice parties, which decided to give high positions to women, would thus be represented by $34 \%$ and $17 \%$ female members of parliament accordingly. On the electoral lists of the Polish Peasants Party, only few women started from a high position, which translated into just $7 \%$ of female members of the parliament in the parliamentary club of this party. The practice of the election committees showed that it was not the placement of women on the list itself which was important, but rather the position which they occupied ${ }^{26}$.

\section{Attempts at introducing the zipping system to electoral lists}

The draft of the amendment to the Electoral Code from August 2011 was received by the Marshal of the Sejm - Mrs. Ewa Kopacz in October 2012. The amendment proposed by the Palikot Movement aimed at introduction of parities and the alternate appearance of the male and female candidates on electoral lists. The proponents justified that only such a solution will guarantee political equality of women and men in the political life ${ }^{27}$. What raised doubts in the provision regarding the parties

22 On the basis of data from the National Electoral Commission, http://wybory2011.pkw.gov.pl/ wsw/pl/000000.html (accessed on: 13 grudnia 2014).

23 Ibidem.

24 Ibidem.

25 Ibidem.

26 Ibidem.

27 A parliamentary bill, Sejm paper No. 1146, at: www.sejm.gov.pl (accessed on: 13 December 2014). 
was its constitutionality. The opinion issued by Mr. Andrzej Seremet indicated that the parity solution was not compliant with the Constitution, as gender was not an objective evaluation criterion and might lead to unjustified inequality ${ }^{28}$. In January 2013 Marshal Ewa Kopacz received another draft act prepared by the Parliamentary Group of Women - on amendment to the Electoral Code Act ${ }^{29}$ of July 2011. The said draft consisted in the introduction of the alternate appearance of women and men on electoral lists to the Sejm, municipality, city and district councils as well as provincial assemblies and European Parliament. The proponents raise the argument that the practices in drawing up the electoral lists are clearly in favour of men. "It would be fair if the same percentage of persons - 3 women and 3 men respectively was awarded the first position on the list ${ }^{30}$. In both rationales, it was acknowledged that the quota solution per se was not an effective mechanism, as demonstrated by the parliamentary elections in the year 2011. It was indicated that the practice of application of the current legal regulations did not fully ensure equality between women and men with regards to putting them on the electoral lists. On top of this, there were voices that the zipping system would not cause any changes and might even make the current situation worse. Jarosław Flis, in his opinion on the draft acts that introduced the parity on the electoral lists argues that the act would not, most probably, bring about any of the intended final effects ${ }^{31}$. The exertion of pressure on political parties to put women higher on the electoral lists may turn out to be ineffective, as $90 \%$ of positions in the Polish electoral system does not give chances for election ${ }^{32}$. This follows from the model of open electoral lists and the conviction of the parties that only a candidate ranked first is able to win the elections, therefore the most recognized politicians occupy the highest positions on the electoral lists ${ }^{33}$. Although in May 2014, the draft act submitted by the Parliamentary Group of Women was adopted by the extraordinary committee, the work on the proposed solutions still lasts.

\section{Summary}

The introduction of the mechanism that ensures a greater participation of women in the Polish parliament was a long-lasting process which was initiated in the 1990's and came to an end no sooner than in 2011. The adopted Quota Act is

28 M. Seremet, Ocena poselskiego projektu ustawy o zmianie ustawy - Kodeks wyborczy, Sejm paper No.1146, p. 7.

29 A parliamentary bill, Sejm paper No. 1151, at:www.sejm.gov.pl, (accessed on: 13 December 2014).

$30 \quad$ Ibidem, p. 2.

31 J. Flis, Opinia w sprawie projektów ustaw wprowadzających parytet na listach wyborczych (druk nr 1146 i 1151), p. 1.

32 Ibidem, p. 8.

33 Ibidem, p. 9. 
a compromise between the draft act proposed within the framework of the citizen's legislative initiative and the regulations agreed by the Polish legislator. Shortly after passing the amendment to the electoral law, there appeared an opportunity to check the effectiveness of the adopted mechanism. After the parliamentary elections in the year 2011, the number of women in the Sejm increased by 3.9 percentage points in comparison with the term of office of the Sejm in the year 2007. The reason for such a minor increase can be associated with the internal policies of the parties applied during the distribution of positions on electoral lists. Despite the fact that the parties abode by the requirement of $35 \%$ with a certain surplus, women would not always be put on favourable positions on the candidate lists. The practice of the Polish elections shows that the higher the occupied position of the candidate on the list is, the higher is the probability of their victory. Therefore, the Parliamentary Group of Women and the Palikot Movement drew up an amendment to the electoral regulations, proposing the introduction of the zipping system on the electoral lists. They raised an argument that the zipper quota mechanism was a more effective solution because of the compulsion related to the alternate appearance of female and male candidates on electoral lists. The zipping practice applied by the Civic Platform party during the drafting of the electoral lists in the year 2011 turned out to be more advantageous for female candidates and allowed their presence in the Polish Parliament. Also, there are opinions that the introduction of the zipper quota may not contribute to an increase in the participation of women in politics at all. As the work on the Polish draft zipper quota act still continue, and there is no unambiguous opinion on the effectiveness of the amendment, it will only be possible in practice to prove its effectiveness. The consequence of the currently applicable legal solution is an increase in the number of female candidates on electoral lists. The facilitated access to the electoral lists may, in the long run, help women exist on the political stage, and thus, increase their chances for victory in the next elections.

\section{BIBLIOGRAPHY}

Balińska B., Polityka równości płci. Polska 2007 Raport, Warszawa 2007

Czaplicki K.W., Dauter B., Jaworski S.J., Kisielewicz A., Rymarz F., Kodeks wyborczy. Komentarz, Wolters Kluwer, Warszawa 2014

Dunaj B., Wielki słownik języka polskiego, Warszawa 2009

Fuszara M., Kwoty, listy wyborcze i równość płci w wyborach parlamentarnych w 2011 roku, Instytutu Spraw Publicznych, Warszawa 2012

Fuszera M., Kobiety, wybory, polityka, Instytut Spraw Publicznych, Warszawa 2013

Rakowska A., Skotnick K., Zmiany w prawie wyborczym wprowadzone przez kodeks wyborczy, "Przegląd Sejmowy" 2011, No. 4(105) 


\section{Paula Wiśniewska}

Raciborski, F., Raciborski J., Kobiety w roli paprotek. The internet edition of 'Rzeczpospolita', 28.08.2009 at: http://www.rp.pl/artykul/9133,355026.html (accessed on: 13.11.2014)

Skotnicki K., Szmyta A., Wieruszowski R., Sękowska-Kozłowska K., Opinie w sprawie wprowadzenia parytetu płci na listach wyborczych, "Przegląd Sejmowy" 2010, No. 3(98)

Siemieńska R., Płeć, wybory, władza, Friedrich Ebert Stiftung 2005, Warszawa 2005

Szewczyk M., Parytet płci w ujęciu prawno porównawczym, Studia Iuridica Toruniensia, tom 9/211, Wydawnictwo Naukowe Uniwersytetu Mikołaja Kopernika w Toruniu, Torun 2011

Wawrowski Ł., Polityka równych szans. Instytucjonalne mechanizmy zwiększania partycypacji ko- biet w strukturach politycznych na przykładzie państw Unii Europejskiej, Wydawnictwo Adam Marszałek, Toruń 2007

Wawrowski Ł., Co da Polkom tzw. ustawa parytetowa? Studia BAS No. 2(26) 2011, Warszawa 2011

Żukowski A., Partycypacja wyborcza kobiet - wyzwania i dylematy, Centrum Studiów Wyborczych, Toruń 2011 